\title{
BRITISH MUSEUM NATURAL RADIOCARBON MEASUREMENTS XIII
}

\section{RICHARD BURLEIGH and KEITH MATTHEWS}

\section{Research Laboratory, The British Museum, London} WG1B 3DG, England

The following list consists of dates for archaeologic samples mostly measured from July 1976 to December 1977*. The dates were obtained by liquid scintillation counting of benzene using the laboratory procedures outlined in previous lists (see, eg, BM-VIII, R, 1976, v 18, p 16). Dates are expressed in radiocarbon years relative to AD 1950 based on the Libby half-life for ${ }^{14} \mathrm{C}$ of $5570 \mathrm{yr}$, and are corrected for isotopic fractionation $\left(\delta^{13} \mathrm{C}\right.$ values are relative to PDB $)$. No corrections have been made for natural ${ }^{1+} \mathrm{C}$ variations (although in some instances approximate calibrated dates taken from the tables of R M Clark (1975) have been given in the comments where this aids interpretation of results). The modern reference standard is NBS oxalic acid (SRM 4990). Errors quoted with the dates are based on counting statistics alone and are equivalent to \pm 1 standard deviation $( \pm 1 \sigma)$, Dates in this and the next list (BMXIV) reported to submitters or published elsewhere before the introduction of the new guidelines for rounding of computed figures have deliberately been left unrounded. From BM-XV onwards all BM dates will be rounded before publication in conformity with the recently recommended procedures ( $\mathrm{R}, 1977$, v 19, p 362). Descriptions, comments, and references to publications are based on information supplied by submitters.

\section{SAMPLE DESCRIPTIONS}

\section{ARCHAEOLOGIC SAMPLES}

\section{A. British Isles}

BM-731. Blagdon, Somerset

$\mathbf{3 2 4 5} \pm \mathbf{3 7}$ $\delta^{13} C=-19.3 \%$ o

Collagen from proximal end of left radius of skeleton of wild aurochs (Bos primigenius Bojanus) from archaeol deposit in limestone fissure at Charterhouse Warren Farm, Blagdon, Mendip, Somerset, England $\left(51^{\circ}\right.$ $20^{\prime} \mathrm{N}, 2^{\circ} 45^{\prime} \mathrm{W}$, Natl Grid Ref ST 494545). Coll 1971 and subm 1976 by R F Everton, Univ Bristol Spelaeol Soc. Remains were loosely assoc with Iron age pottery, and horn cores had cut-marks supposedly made with iron sword (Everton, 1975), suggesting late date. Measured as part of program for dating late-Glacial and Postglacial mammals in British Isles. Comment (RB): although one of latest results so far obtained for survival of Bos primigenius in Britain, date still lies fully within middle Bronze age (Burleigh and Clutton-Brock, 1977).

* Dates obtained over the same period for samples from Grime's Graves, Norfolk, England, formed part of a separate list, BM X (R, 1979, v 21, p 41-47). 


\section{Callis Wold series, Yorkshire}

Charcoal samples from Barrow 275, Callis Wold, Bishop Wilton, Yorkshire, England (54 $4^{\circ}$ N, $0^{\circ} 45^{\prime} \mathrm{W}$, Natl Grid Ref SE 832559). Coll 1974 and subm by D G Coombs, Dept Environment, to date Neolithic platform burial assoc with Towthorpe ware, and later Beaker deposit.

BM-1167. Callis Wold

$4803 \pm 71$

Sample ref CW74 III 31; burned plank from bedding trench $\mathrm{S}$ of platform.

$\delta^{13} C=-25.5 \%$

\section{BM-1168. Callis Wold}

$\mathbf{3 7 9 4} \pm \mathbf{7 0}$

Sample ref CW74 II 31; continuation of CW74 II 29 (BM-1169, below) under turf mound.

\section{BM-1169. Callis Wold}

Sample ref CW74 II 29; from layer with All-Over-Cord, European, Plain and Finger Nail Beakers ( $c f$ BM-1168, above).

\section{BM-1170. Callis Wold}

$4933 \pm 64$

Sample ref CW74 III 18; from upper fill of bedding trench containing Neolithic Towthorpe ware.

General Comment (DGC): BM-1167, -1170 relate to straight facade trench at front of burial complex (Coombs, 1976) containing burial platform excavated by Mortimer (1905, p 161-163) and are first radiocarbon dates directly assoc with Neolithic Iowthorpe ware, contained in upper fill of trench; dates compare favorably with those for comparable Neolithic burial structures (eg, Wayland's Smithy, Berks; Aldwincle, Northants). BM-1168, -1169 relate to Beaker level found on top of small and mound covering Neolithic burials and agree with other dates for similar Beakers.

\section{BM-1181 Great Wilhraham, Cambridgeshire}

Wood (Quercus sp) from site of henge monument at Great Wilbraham, Cambridgeshire, England $\left(52^{\circ} 10^{\prime} \mathrm{N}, 0^{\circ} 15^{\prime} \mathrm{E}\right.$, Natl Grid Ref TL 550570). Coll 1975 and subm by D L Cilarke, Dept Archaeol, Univ Cambridge. Comment (RB): sample refluxed with hot water to remove polyethylene glycol used as a consolidant; wood was worked and came from peat deposit cut by later henge monument; expected to be of Mesolithic date, but evidently derived from much later human activity at site.

\section{Orsett series, Essex}

Charcoal samples from Neolithic causewayed enclosure at Orsett, Tilbury, Essex, England ( $51^{\circ} 30^{\prime} \mathrm{N}, 0^{\circ} 20^{\prime} \mathrm{E}$, Natl Grid Ref TQ 653 806). Coll 1975-1976 and subm by J D Hedges, Essex Co Council, to date construction and occupation phases of monument (Hedges and Buckley, 1978). 
BM-1213. Orsett

$4741+113$

Sample ref $1731 / \mathrm{BF} 14$ (3); charcoal from post-hole in palisade entrance, NW side of enclosure.

\section{BM-1214. Orsett}

$4533 \pm 112$

Sample ref 1731/BF2 II (6); charcoal from top of primary silts of middle ditch, assoc with Mildenhall pottery.

BM-1215. Orsett

$4585 \pm 82$ inner ditch, assoc with Mildenhall pottery.

\section{BM-1377. Orsett}

$4620 \pm 43$

Sample ref 1731/BF 45 (3); charcoal from pit $S$ of palisade.

\section{BM-1378. Orsett}

$4.726 \pm 74$

Sample ref $1731 / \mathrm{BF} 85$ (4); charcoal from post-hole in central gate structure of causeway entrance. Comment (JDH): sample came from sealed context of post-hole within larger post-pit central to causeway of middle interrupted ditch. Post-pit contained sherds of Mildenhall-style pottery; date corresponds closely with BM-1213 (above) and suggests that timber causeway entrance structure was contemporary with palisade.

\section{BM-1379. Orsett}

$2514 \pm 81$

Sample ref 1731/CF4 I (3); charcoal from upper silts of inner causewayed ditch. Comment (JDH): date is consistent with final phase of silting within inner causewayed ditch, which contained early Iron age pottery.

\section{BM-1380. Orsett}

$3871 \pm 62$ circuit of causewayed ditch. Comment (JDH): middle silts of inner ditch contained Grooved ware sherds of Clacton sub-style; date is appropriate for this horizon.

\section{Eskmeals series, Cumbria}

Charcoal from features on Mesolithic occupation sites at Monk Moors and Williamson's Moss, Eskmeals, Cumbria, England $\left(54^{\circ} 20^{\prime} \mathrm{N}, 3^{\circ} 25^{\prime}\right.$ W, Natl Grid Ref SD 085920). Coll 1974-1977 and subm by J C Bonsall, Dept Archaeol, Univ Edinburgh.

\section{BM-1216. Monk Moors, Eskmeals}

$6752 \pm 156$

Charcoal, ref Sample 2, from Site 1, Feature 134. 
BM-1385. Monk Moors, Eskmeals

Charcoal, ref Sample 3, from Site 2, Feature 1.

BM-1386. Monk Moors, Eskmeals

Charcoal, ref Sample 4, from Site 2, Feature 33.

BM-1395. Monk Moors, Eskmeals

Charcoal, ref Sample 5, from Site 1, Feature 399.

\section{BM-1396. Williamson's Moss, Eskmeals}

Charcoal, ref Sample 1, from Site 1, Feature 23.
$4028 \pm 54$

$\delta^{13} C=-26.4 \%$

$2859 \pm 49$

$\delta^{13} C=-26.5 \%$

$3654 \pm 118$

$\delta^{13} C=-24.6 \%$

$\mathbf{3 7 5 6} \pm \mathbf{1 0 4}$

$\delta^{13} C=-26.0 \%$

General Comment (JCB): samples coll from hearths and other features on sites assoc with main Postglacial raised shoreline. Only BM-1216 falls

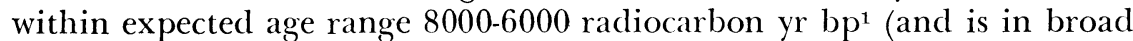
agreement with Q-1356 (unpub) on charcoal from same feature); other determinations (BM-1385, -1386, -1395, -1396) must be regarded as invalid, as features to which they relate have unequivocal late Mesolithic assoc (Bonsall, 1981).

\section{Fisher's Green series, Essex}

Peat samples from gravel pit at Fisher's Green, $2 \mathrm{~km} N$ of Waltham Abbey, valley of R Lea, Essex, England $\left(51^{\circ} 40^{\prime} \mathrm{N}, 0^{\circ} 0^{\prime} \mathrm{E}\right.$, Natl Grid Ref TL 377026). Coll 1974 and subm by J C Bonsall, to date uniserially barbed antler point found assoc with peat.

\section{BM-1241. Fisher's Green}

Peat, ref $\mathrm{S} 1$, base, $10 \mathrm{~cm}$ above peat/sand boundary.

\section{BM-1242. Fisher's Green}

Peat, ref S2, top, $40 \mathrm{~cm}$ above peat $/$ sand boundary.
$8390 \pm 70$ $\delta^{13} C=-26.7 \%$

$$
\begin{array}{r}
\mathbf{5 4 9 0} \pm \mathbf{7 0} \\
\delta^{13} C=-25.1 \%
\end{array}
$$

General Comment (JCB): there are only two reliably dated occurrences of this type of barbed point in Britain, at High Furlong, Lancashire (St-3832, 12,200 \pm 160; St-3836, 11,665 \pm 140; Hallam et al, 1973, p 110) and Star Carr, N Yorkshire (Clark, 1954; Q-14, $9557 \pm 210 ; \mathrm{R}, 1959$, v 1, p 69). Fisher's Green dates are at variance with results of pollen analysis of peat, and their validity must be in question.

\section{Blashenwell series, Dorset}

Samples of mammalian bone (prob Cervus elaphus) from kitchen midden in Blashenwell tufa, Blashenwell Farm, near Corfe, Dorset, England $\left(50^{\circ} 40^{\prime} \mathrm{N}, 2^{\circ} 5^{\prime} \mathrm{W}\right.$, Natl Grid Ref SY 952805). Coll ca 1895 by Clement Reid and subm 1976 by R C Preece and M P Kerney, Dept Geol, Imperial Coll, London, from colln of Dorset Co Mus, Dorchester,

${ }^{1}$ British convention for uncorrected radiocarbon dates 
to provide dates for molluscan biostratigraphy of Mesolithic site (Bury, 1950; Preece, 1980; Reid, 1896). Stratigraphic horizon of samples not recorded (see General Comment, below).

\section{BM-1257. Blashenwell}

Collagen from mammalian bone, ref DCM1.

\section{BM-1258. Blashenwell}

Collagen from mammalian bone, ref DCM2.
$5750+140$ $\delta^{13} C=-21.4 \%$

$5425 \pm 150$ $\delta^{13} C=-22.7 \%$

General Comment (RCP and MPK): dates are younger than previously pub date from site $(\mathrm{BM}-89,6450 \pm 150$ : $\mathrm{R}, 1961, \mathrm{v} 3, \mathrm{p}$ 40; bone from middle zone of tufa, not directly related to molluscan sequence), but Mollusca from marrow cavities of bones dated by BM-1257, -1258 are referable to Zone d of sequence proposed by Kerney (1977). Also, dates are consistent with those obtained for similar assemblages elsewhere (Kerney, 1976; Kerney, Preece, and Turner, 1980; Preece, 1978), and suggest bones are from upper levels of tufa (Preece, 1980). Direct dating of nodules from base of tufa (HAR-3766, unpub) gives corrected age range of 9400-8900 вP for onset of tufa formation at Blashenwell, in agreement with biostratigraphic prediction (Thorpe, in Preece, 1980, p 361). Dates for bone are all from Mesolithic midden material and indicate occupation of site over 1000-yr period.

\section{BM-1367. Paviland, W Glamorgan}

$27,600 \pm 1300$

$\delta^{13} C=-19.9 \%$

Collagen from distal part of fragmentary left humerus (ref 24.94 171) of Bos primigenius or Bison sp (id by Juliet Clutton-Brock, Dept Zool, British Mus (Nat Hist)), from deposits containing Upper Palaeolithic artifacts in Goat's Hole Cave, Paviland, Gower Peninsula, W Glamorgan, $S$ Wales $\left(51^{\circ} 35^{\prime} \mathrm{N}, 4^{\circ} 15^{\prime} \mathrm{W}\right.$, Natl Grid Ref SS 437859). Coll 1912 by W J Sollas and subm 1977 by Theya Molleson, Subdept Anthropol, British Mus (Nat Hist) from colln of Natl Mus Wales, Cardiff. Comment (RB): date allows presence of typologically early artifacts in cave (now completely cleared of original deposits) to be reconciled with date of $18,460 \pm 340$ (BM-374: R, 1969, v 11, p 289) previously obtained for postcranial bones of "Red Iady" of Paviland (Molleson and Burleigh, 1978).

\section{BM-1374. Godmanchester}

$2135 \pm 152$

Collagen from femur (ref ARC 72.5036) of domestic dog from Pit K 103 (494A), Pinfold Lane, Godmanchester, Huntingdonshire, England $\left(52^{\circ} 20^{\prime} \mathrm{N}, 0^{\circ} 10^{\prime} \mathrm{W}\right.$, Natl Grid Ref TL, 250700). Coll 1970 by $\mathrm{H}$ J M Green for Dept Environment and subm 1977 by Juliet Clutton-Brock to verify dating of $\log$ for archaeozool purposes and to provide comparative material for carbon isotope studies (BM-1236-1240, -1359-1364, this list, below; Burleigh and Brothwell, 1978, p 357). Comment (RB): expected date, 1st to 3rd century aD (Green, 1969). 


\section{BM-1387. Ardingly, Sussex}

Wood sample (bog oak, Quercus robur L type) id by D F Cutler, Royal Botanic Gardens, Kew, from timbers found during excavation for reservoir, lying horizontally at depth $4 \mathrm{~m}$ in alluvial organic silt at Shell Brook, Ardingly, Haywards Heath, W Sussex, England $\left(51^{\circ} 5^{\prime} \mathrm{N}, 0^{\circ} 10^{\prime}\right.$ W, Natl Grid Ref TQ 335288). Coll 1976 and subm by A D Schilling, Deputy Curator, Royal Botanic Gardens, Kew (Wakehurst Place). Comment (RB): date agrees with expected age of ca 500-1000 yr BP for timbers.

\section{North Stoke series, Oxfordshire}

Samples of antler and charcoal from cursus monument and long mortuary enclosure at North Stoke, Crowmarsh Parish, Oxfordshire, England (51 $35^{\prime} \mathrm{N}, 1^{\circ} 10^{\prime} \mathrm{W}$, Natl Grid Ref SU 611856). Coll 1951-1952 and subm 1976 by H J Case, Dept Antiquities, Ashmolean Mus, Oxford (Case, 1959; Catling, 1959).

\section{BM-1405. North Stoke}

$4672 \pm 49$

Collagen from red deer antler, ref Sample 1, from primary silt of W ditch of cursus.

\section{BM-1406. North Stoke}

$3374 \pm 83$

$\delta^{13} C=-25.0 \%$

Charcoal from cremation pit with miniature Collared Urn, within long mortuary enclosure (Oxoniensia, 1951, v 16, p 81, fig 19).

General Comment (HJC): BM-1405 is 1st date available for cursus monument and agrees with expectations (cf BM-355, $4460 \pm 140$, date for antler from Middle Neolithic enclosure at Abingdon ca $19 \mathrm{~km}$ to W; R, 1971, v 13, p 171). BM-1406 also agrees with expectations (cf GrN-1686, 3440 \pm 60 , date for charcoal assoc with small Secondary Series Collared Urn from City Farm, Hanborough, ca $35 \mathrm{~km}$ to W; R, 1964, v 6, p 356).

\section{Mylodon Cave series}

\section{B. Chile}

Samples of mylodon and guanaco bone, charcoal, mylodon dung, and owl pellets from levels in Mylodon Cave, Ultima Esperanza $\left(51^{\circ} 35^{\prime} \mathrm{S}\right.$, $72^{\circ} 35^{\prime} \mathrm{W}$ ). Coll 1976 and subm by E C Saxon, Dept Anthropol, Univ Durham, to date alternating occupation of cave by mylodon (giant sloth) and man (Saxon, 1979); of date previously obtained for mylodon bone from colln of British Mus (Nat Hist): 12,984 $\pm 76, \mathrm{R}, 1977$, v 19, p 143.

BM-1201. Mylodon Cave

$5366 \pm 55$ $\delta^{13} C=-23.1 \%$

Charcoal from Trench 2, Layer 7. Comment (ECS): artifacts assoc with butchered guanaco bone; mylodon absent.

BM-1201A. Mylodon Cave

$5395 \pm 58$

Charcoal from Trench 2, Layer 7. Recount of BM-1201. 
BM-1202. Mylodon Cave

$2556 \pm 45$

Charcoal from Nordenskjold midden, Layer A Comment (ECS): artifacts assoc with guanaco bone and Mytilus shells; no evidence of mylodon.

BM-1203. Mylodon Cave

$7803 \pm 82$

Owl pellets from Trench 3, Layer 6.9w. Comment (ECS): humid forest replaces boggy grassland vegetation; guanaco replace mylodon in cave deposit.

\section{BM-1204. Mylodon Cave}

$5684 \pm 52$

Charcoal from Trench 2, Layer 7. Comment (ECS): artifacts assoc with butchered guanaco bone; mylodon absent.

BM-1204B. Mylodon Cave

$5643 \pm 60$

Charcoal from Trench 2, Layer 7. Recount of BM-1204.

BM-1207. Mylodon Cave

$7785 \pm 747$

Burned guanaco bone from Trench 2, Layer 9.1. Comment (ECS): artifacts assoc with butchered guanaco bone; mylodon absent.

BM-1208. Mylodon Cave

$13,183 \pm 202$

$\delta^{13} C=-22.4 \%$

Collagen from mylodon bone from Trench 2, Layer 10. Comment (ECS): glacial retreat sufficient for mylodon to enter cave.

BM-1209. Mylodon Cave

$12,496 \pm 148$

$\delta^{13} C=-25.6 \%$

Mylodon dung from Trench 5, Layer 1. Comment (ECS): ca $1 \mathrm{~m}$ layer of rapidly accumulated mylodon dung; of BM-1210, -1210B, -1375, below.

BM-1210. Mylodon Cave

$11,810 \pm 229$ $\delta^{13} \mathrm{C}=-28.6 \%$

Mylodon dung from Trench 5, Layers 14-15; cf BM-1209, above, and $-1210 \mathrm{~B},-1375$, below.

BM-1210B. Mylodon Cave

$12,308 \pm 288$

Mylodon dung from Trench 5, Layers 14-15. Recount of BM-1210.

BM-1375. Mylodon Cave $12,552 \pm 128$ $\delta^{13} \mathrm{C}=-26.1 \%$ above.

Mylodon dung from Trench 5, Layer 10; cf BM-1209, -1210, -1210B,

\section{Cueva de la Antigua series}

C. Colombia

Charcoal from occupation site at Cueva de la Antigua, Municipio San Gil, Dept Santander $\left(6^{\circ} 35^{\prime} \mathrm{N}, 73^{\circ} 10^{\prime} \mathrm{W}\right)$. Coll 1972 and subm by 
W Bray, Inst Archaeol, Univ London, to date beginning and end of Antigua phase occupation at site.

\section{BM-1381. Cueva de la Antigua}

$1540 \pm 200$ phase.

Charcoal from Unit Y2, base of ashy stratum with sherds of Antigua

BM-1382. Cueva de la Antigua

$$
\delta^{13} C=-23.2 \%
$$

Charcoal from Unit Y2, Spit 7, upper interface of Antigua-phase occupation.

General Comment (WB): determinations fall within range of previous dates for Antigua strata at this site (BM-804, -805, -806: R, 1977, v 19, p 144) and conform with stratigraphic position (separated by sterile layer from overlying Carrizal ceramics).

BM-1384. Finca Llano de los Gallos

$$
\mathbf{3 8 0} \pm \mathbf{8 0}
$$

Charcoal, ref Los Gallos A (Extension), I vel III, from test pit a Finca Llano de los Gallos, Municipio Los Santos, Dept Santander $\left(6^{\circ}\right.$ $45^{\prime} \mathrm{N}, 73^{\circ} 5^{\prime} \mathrm{W}$ ). Coll 1972 and subm by W Bray, to date assoc pottery style related to Carrizal ware. Comment (WB): date corroborates archaeol data; this style of pottery was made by Guane Indians who occupied region of Los Santos at time of European conquest.

\section{Knossos series}

$$
\text { D. Crete }
$$

Charcoal samples from Neolithic levels in soundings in W Court of Minoan Palace of Knossos, N central Crete (35 $\left.30^{\prime} \mathrm{N}, 25^{\circ} 10^{\prime} \mathrm{E}\right)$. Coll 1970 and subm by J D Evans, Inst Archaeol, Univ London. (For previous series of dates for pre-Palace settlement at Knossos, see R, 1963, v 5, p 104-105; R, 1969, v 11, p 279-280; R, 1977, v 19, p 145; Evans, 1971).

BM-716. Knossos

$5003 \pm 213$

Charcoal, ref W Court, Sounding FF, Level 38, Sample 3, Final Neolithic.

$\delta^{13} \mathrm{C}=-25.0 \%$

\section{BM-717. Knossos}

$5806 \pm 124$

Charcoal, ref W Court, Sounding El Neolithic.

\section{BM-718. Knossos}

$5892 \pm 91$

Charcoal, ref W Court, Sounding EE, Level 27, Sample 23; Level 34 Samples 27-29, Middle Neolithic. 
BM-719. Knossos

$5967 \pm 41$

$\delta^{13} C=-24.4 \%$

Charcoal, ref W Court, Sounding AA/BB, Level 164, Sample AR (IA); Level 174, Sample AY (IA); Level 181, Sample BA (IA); Level 183, Sample BI (IA), Early Neolithic II.

\section{BM-1371. Knossos}

$6201 \pm 252$

Charcoal, ref W Court, Sounding AA/BB, Level 272, Sample CW (II); Level 277, Sample GY (II), Early Neolithic I.

\section{BM-1372. Knossos}

$6482 \pm 161$

Charcoal, ref W Court, Sounding AA/BB, Level 279, Samples CM, DF, DG (II); Level 286, Sample CL (II), Early Neolithic I.

General Comment (JDE): end of EN I phase at ca $4200-4100$ bc is confirmed by BM-1371 and -719, which support previous dates for late EN I and EN II (BM-274, -577), though contradicting another for late EN I (BM-126); MN and LN dates (BM-718, -717) are rather old in comparison both with BM-274 and -577 , and with previous dates for MN and LN at Knossos (BM-575, -579 and -581 ), but confirm impression that both EN II and MN were very short phases. Date for Final Neolithic (BM-716) is very striking; although it fits quite well with $\mathrm{LN}$ dates, suggesting longish LN phase, if calibrated, it seems to imply very old date for beginning of Early Minoan period.

\section{Hierakonpolis series}

$$
\text { E. Egypt }
$$

Shells of freshwater Mollusca from Tomb 100 (Decorated Tomb) at Hierakonpolis, on $\mathrm{W}$ bank of $\mathrm{R}$ Nile $\mathrm{N}$ of Edfu, Nubia, Upper Egypt $\left(25^{\circ} 10^{\prime} \mathrm{N}, 32^{\circ} 45^{\prime} \mathrm{E}\right)$. Coll $1898-1899$ by F W Green and subm 1976 by Joan Crowfoot Payne, Dept Antiquities, Ashmolean Mus, Oxford, from reserve colln of Cambridge Mus Archaeol and Anthropol, to provide date for important Predynastic (Gerzean) tomb in absence of alternative sample material; modern live-coll shells of related sp from Nile Valley from colln of Dept Zool, British Mus (Nat Hist) dated to assess probable hard-water effect.

\section{BM-1127A. Hierakonpolis (Tomb 100)}

$12,911 \pm 118$

Shell carbonate (aragonite) from 5 separate valves of Unio willcocksi RB Newton, from Tomb 100, ref 1973.1025, z15390e, f, h, i, j.

BM-1127B. Hierakonpolis (Tomb 100)

$5003 \pm 88$

Shell carbonate (aragonite) from single valve of Etheria elliptica Lamarck, from Tomb 100, ref 1973.1025, z15390p. 


\section{BM-1342. Shell carbonate}

$2200 \pm 70$

$\delta^{13} C=-6.0 \%$

Shell carbonate (aragonite) from single valve of Unio sp from Nile Valley, date of coll unknown (date suggests sub-fossil rather than live-coll shell).

\section{BM-1343. Shell protein}

$3030 \pm 520$

Shell protein (conchiolin) from single valve of Unio sp from Nile Valley, date of coll unknown (date suggests sub-fossil rather than live-coll shell).

BM-1344. Shell carbonate

$$
200 \pm 40
$$

Shell carbonate (aragonite) from single valve of Etheria elliptica, live-coll, Nile Valley, ca AD 1920.

\section{BM-1345. Shell carbonate}

$\mathbf{5 8 0} \pm \mathbf{4 0}$ Lamarck (Unionidae), live-coll, Nile Valley, AD 1941. Other valve used to provide protein sample, BM-1346, below.

\section{BM-1346. Shell protein}

$$
640 \pm 180
$$

Shell protein (conchiolin) from single valve of Aspatharia rubens. Other valve used to provide carbonate sample, BM-1345, above.

General Comment (RB): BM-1127A dates fossil shells of Unio willcocksi that probably derive from nearby deposits corresponding to major episode of Nile accumulation (Sahaba-Darau aggradation event; Fred Wendorf, written commun; Wendorf and Schild, 1976, p 278-280), and may have been deliberately placed in tomb; date for Etheria elliptica (BM-1127B) agrees with C-812, $5020 \pm 290$ (Libby, 1955, p 79), date for human hair and skin from Grave T56 at Naqada of Naqada II period to which Tomb 100 at Hierakonpolis belongs. Dates for live-coll shells (BM-1344-1346) suggest hard-water effects of ca 600 and $200 \mathrm{yr}$ for Unio and Etheria elliptica, respectively. Result for E elliptica (BM-1127B) corrected on this basis and calibrated from tables of R M Clark (1975) gives date of ca 3650 BC for Tomb 100, in good agreement with archaeol evidence (Adams, 1974, p 86; Burleigh, $\mathrm{ms}$ in preparation; Case and Payne, 1962; Payne, 1973; Quibell and Green, 1902, p 20-22, pl LXVII).

\section{Tell el-Dab'a}

Charcoal samples from Tell el-Dab'a $\left(25^{\circ} 40^{\prime} \mathrm{N}, 32^{\circ} 25^{\prime} \mathrm{E}\right)$, representing conflagration layers connected with rise of Hyksos rule in Egypt, ca 1650 вс. Coll 1974 and subm by M Bietak, Österreichische Botschaft Kairo, Vienna.

BM-1165. Tell el-Dab'a

$$
3400 \pm 113
$$

Charcoal, ref Sample 43, AII-n11, layer above St G, W sec (12th Dynasty). 


\section{BM-1225. Tell el-Dab'a}

$3436 \pm 43$

Charcoal from conflagration layer.

General Comment (RB): dates agree with archaeol evidence (Bietak, 1979); mean calibrated date from tables of R M Clark (1975) is ca 1800 BC (12th Dynasty).

\section{Saqqara series}

Samples of charcoal and chopped straw from Tomb of Horemheb, New Kingdom Necropolis, Saqqara (295 $50^{\prime}$ N, $31^{\circ} 15^{\prime}$ E). Coll 1976-1978 and subm by G T Martin, Dept Egyptol, Univ Coll, London. Horemheb was Commander-in-Chief and Regent of Tutankhamūn, and King of Egypt from ca 1335 вс; samples should date to end of 18th Dynasty, ca 1350 BC. Few samples from Egyptian New Kingdom period have been dated by radiocarbon.

\section{BM-1211. Saqqara}

$2867 \pm 65$

Chopped straw from mud-plaster from $\mathrm{N}$ wall of Statue Room of Tomb of Horemheb. Calibrated date (Clark, 1975) is ca $1150 \pm 100$ BC.

\section{BM-1370. Saqqara}

$\mathbf{3 0 3 2} \pm \mathbf{5 7}$

Chopped straw from mud-plaster from $\mathrm{E}$ end of $\mathrm{S}$ wall of First Court of Tomb of Horemheb. Wall was surfaced with limestone blocks decorated with reliefs depicting scenes in career of tomb owner; plaster must be contemporary with building of tomb (Martin, 1976). Calibrated date (Clark, 1975) is ca $1350 \pm 100 \mathrm{BC}$.

\section{BM-1641. Saqqara}

$2910 \pm 40$

Charcoal from $3.5 \mathrm{~kg}$ cache found in Pillared Hall, $\mathrm{N}$ of subterranean complex of Shaft IV of Tomb of Horemheb. Presumed to relate to burial made ca 1323-1321 BC (from evidence of inscribed wine amphora; Martin, 1979, p 15), but calibrated date (Clark, 1975) is ca $1190 \pm 100$ вC (cf BM1211, above).

General Comment (RB \& GTM): BM-1370 agrees with historic evidence for date of Horemheb and BM-1211 probably represents embellishment and replastering of Statue Room for cult of Horemheb in Ramesside period, but date of ca $1190 \pm 100 \mathrm{BC}$ for charcoal from Shaft IV (BM1641) is inexplicable at present as no archaeol evidence was found for later use of this part of tomb.

\section{Egyptian axe series}

Samples of wood from hafts of ceremonial bronze axes and one box with decoration depicting an axe, in colln of Dept of Egyptian Antiquities, British Mus, from various localities in Egypt $\left(\right.$ ca $\left.30^{\circ} \mathrm{N}, 31^{\circ} \mathrm{E}\right)$. Coll 1842-1925 and subm 1976 by W V Davies, Dept Egyptian Antiquities, British Mus, to provide confirmatory dates for hafts of axes dated by inscription, typol or metal analysis, as part of projected catalogue of 
Ancient Egyptian tools and weapons in British Mus colln (Davies, ms in preparation). Wood id by Rowena Gale, Jodrell Lab, Royal Botanic Gardens, Kew. Approx calibrated dates from tables of R M Clark (1975).

\section{BM-1245. Axe-haft}

$3570 \pm 60$

Wood (Tamarix sp) from haft of 1st Intermediate Period/Middle Kingdom axe, EA58074 (ca 2100-1780 BC); calibrated date ca $2000 \pm 110$ BC.

BM-1246. Axe-haft

$4470 \pm 70$

Wood (Acacia sp) from haft of New Kingdom axe, EA65663 (ca 1500 $\mathrm{BC})$; calibrated date ca $3270 \pm 120 \mathrm{BC}$.

BM-1247. Axe-haft

$3580 \pm 90$ Dynasty, ca $1400 \mathrm{BC}$ ); calibrated date ca $2010 \pm 130 \mathrm{BC}$.

\section{BM-1248. Wooden box}

$$
3310 \pm 70
$$

Wood (Ficus sp) from Middle Kingdom/2nd Intermediate Period box, EA20648 (ca 1850-1550 BC) with painted depiction of axe; calibrated date ca $1660 \pm 115 \mathrm{BC}$.

\section{BM-1249. Axe-haft}

$3480 \pm 70$

Wood (Ziziphus sp) from haft of 1st Intermediate Period/Middle Kingdom axe, EA30083 (ca 2100-1780 BC); calibrated date ca $1870 \pm 120$ BC.

\section{BM-1250. Axe-haft}

$1840 \pm 70$

Wood (Acacia sp) from shaft of 2 nd Intermediate Period axe, EA65664 (ca $1600 \mathrm{BC}$ ); calibrated date ca $\mathrm{AD} 190 \pm 90$.

\section{BM-1251. Axe-haft}

Wood (Prunus sp) from haft of 1st Intermediate Period/Middle Kingdom axe, EA67479 (ca 2100-1780 BC); calibrated date ca $1980 \pm 110$ BC.

General Comment (RB): four of dates (BM-1245, -1248, -1249, -1251) conform with expected historic dating. Of remaining three, BM-1246 is ca $1800 \mathrm{yr}$ earlier than expected and this probably arises from re-use of older wood in antiquity, as original thong binding axe to haft appears undisturbed. BM-1250 is ca $1800 \mathrm{yr}$ later than expected and evidently represents misassoc of haft dating to Coptic period with older axe broadly dated by metal analysis and typol to 2nd Intermediate Period. BM-1247 dates haft of cedar and is ca $700 \mathrm{yr}$ older than expected, but could represent age of wood at time of 1 st use. For full discussion of results, 
see Burleigh, in Davies (catalogue of Ancient Egyptian tools and weapons in British Mus Colln, in preparation).

\section{BM-1357. Petrie horse \\ $\mathbf{3 2 8} \pm \mathbf{5 2}$ \\ $\delta^{13} \mathrm{C}=-18.8 \%$}

Collagen from right ulna of horse skeleton from Egypt (ca $30^{\circ} \mathrm{N}, 31^{\circ}$ E; exact provenance unknown), from colln of British Mus (Nat Hist), London. Coll ca 1900 by Sir Flinders Petrie and subm 1977 by Juliet Clutton-Brock, Dept Zool, British Mus (Nat Hist), to provide date for fragmentary cranium and complete mandible and skeleton, as part of collaborative program for archaeozool study and dating of early domesticated animal remains. Comment (RB): skeletal remains of horse are rare even from later periods in Egypt, so that this skull and skeleton would have been important if shown by radiocarbon dating to be ancient (3rd-1st millennium BC). Result disproves this, but shows that these remains are relevant to study of early hist of Arab horse in Europe (Clutton-Brock and Burleigh, 1979).

\section{Abu Salabikh series}

$$
\text { F. Iraq }
$$

Charcoal samples excavated from remains of buildings in Early Dynastic tell of Abu Salabikh, Diwaniyah Governorate $\left(32^{\circ} 15^{\prime} \mathrm{N}, 45^{\circ}\right.$ $5^{\prime}$ E). Coll 1975-1976 and subm by J N Postgate, Dir, British Archaeol Exped to Iraq, Baghdad.

BM-1365A. Abu Salabikh

$3938 \pm \mathbf{5 4}$ $\delta^{13} C=-24.4 \%$

Charcoal, ref 6G 64:655 (60), from Area E, Room 39, burned layer on I C floor (roofing material); $c f$ date for separate sample from same locus, $3830 \pm 70$ (HAR-1877, unpub).

BM-1365B. Abu Salabikh

$3963 \pm 57$

Recount of BM-1365A.

$\delta^{13} C=-24.4 \%$

BM-1365C. Abu Salabikh

$3826 \pm 47$ $\delta^{13} \mathrm{C}=-25.1 \%$

Charcoal, ref 6G 64:655 (60), as BM-1365A, but fresh sample.

BM-1365D. Abu Salabikh

$3916 \pm 50$ $\delta^{13} C=-25.6 \%$ sample.

Charcoal, ref 6G 64:655 (60), as BM-1365A-1365C, but further fresh

BM-1366. Abu Salabikh

$3869 \pm 56$

Charcoal, ref 5I 10:184, from carbonized beam lying on Level II floor of Room 1 in Area A, Sq 5I 10b.

BM-1390. Abu Salabikh

$4267 \pm 85$

Charcoal, ref 5I 21:360 (1157). 
General Comment (JNP): calibrated dates (mean of BM-1365A-D, $2460 \pm$ 65 вс; BM-1366, $2410 \pm 80$ вC; BM-1390; $2990 \pm 105$ вC; Clark, 1975) agree with archaeol dates expected (Postgate, 1977; 1978; 1980a; Postgate and Moorey, 1976).

BM-1416. Zibliyat

$1102 \pm 43$ $\delta^{13} C=-23.7 \%$

Reeds (Phragmites australis) id by $S$ Renvoise, Herbarium, Royal Botanic Gardens, Kew, from layers incorporated between mud-brick courses in monument of Zibliyat, tower-like structure $20 \mathrm{~km} \mathrm{NW}$ of Nippur and $5 \mathrm{~km} \mathrm{E}$ of Abu Salabikh, Diwaniyah Governorate $\left(32^{\circ} 20^{\prime} \mathrm{N}, 45^{\circ} 5^{\prime}\right.$ E). Coll 1977 and subm by R Burleigh to provide date for building long believed to be Parthian or Sassanian (250 BC-AD 650), but recently suggested as Islamic. Comment (RB): mud-brick structure of Zibliyat appears to represent single phase of building. Date confirms that it belongs to Islamic (early Abbasid) period (Burleigh, 1980), when it may have been used for regulation or defense of canal system, of which traces survive in neighborhood although area has now reverted to desert. Program is proposed for dating construction and later building phases of other ancient mud-brick structures in Iraq incorporating layers of reeds $(c f$ date for reed rope from brickwork of 2nd stage of ziggurat at Aqar Quf, BM-1477, $3110 \pm 35$; BM-XIV, in press; Postgate, 1980b). Two problems are survival of reeds only as inert ash in some buildings and, unlike situation in Egypt where same procedure already successfully used (see, eg, BM-VII, R, 1971, v 13, p 159-166; BM-IX, R, 1977, v 19, p 149-150), possible presence of bitumen.

\section{G. Israel}

\section{Monastery of St Catherine series, Sinai}

Wood samples from structural timbers in mid-6th century AD Church of the Transfiguration, Monastery of St Catherine, Wadi ed-Deir, $1.6 \mathrm{~km}$ $\mathrm{N}$ of Jebel Musa (Mt Sinai), central Sinai Peninsula $\left(28^{\circ} 45^{\prime} \mathrm{N}, 34^{\circ} 0^{\prime} \mathrm{E}\right)$. Coll 1963-1965 and subm 1974 by G H Forsyth, Kelsey Mus Ancient and Mediaeval Archaeol, Univ Michigan, as check (Sample 65AA) on previous series of dates by Michigan Lab (M-1673-1677; R, 1966, v 8, p 283, M-1812-1814: R, 1968, v 10, p 108), to determine contemporaneity of ceiling of NW tower of church with original nave roof or possible later repair and restoration of roof (Sample 63AB), and contemporaneity of nave roof with supporting trusses (Sample 63AC). Fxpected date, ca AD 550 or later (Forsyth, 1968; Forsyth and Weitzmann, 1973).

BM-1222. Monastery of St Catherine

$1330 \pm 40$

$\delta^{13} C=-24.6 \%$

Wood, ref 65AA, from top of $\mathrm{N}$ end of tie-beam of 2nd truss from $\mathrm{E}$ over nave (sapwood; bark and cut branches visible); cf M-1813, $1280 \pm$ 140. 
BM-1223. Monastery of St Catherine

$1450 \pm 50$ NW corner tower of church.

\section{BM-1224. Monastery of St Catherine}

$1490 \pm 60$

Wood, ref 63AC, cross-sec of purlin from nave roof.

General Comment (GHF): BM-1222 removes previous problem of aberrant date of ca AD 1800 for sample from same location (M-1677) and with BM-1224 confirms that roof frame and sheathing are of original 6th century construction, earlier by some five centuries than similar structures in comparable state of preservation elsewhere; BM-1223 shows that tower ceiling and nave roof are contemporary.

\section{Timna series}

Charcoal samples from early smelting sites in Timna Valley, Wadi Arabah, ca $30 \mathrm{~km} \mathrm{~N}$ of Elat, Gulf of Aquaba $\left(34^{\circ} 55^{\prime} \mathrm{N}, 29^{\circ} 45^{\prime} \mathrm{E}\right)$. Coll ca 1974 and subm by B Rothenberg, Inst Archaeo-Metallurgical Studies, London. (For other dates for Timna, see BM-1115-1117, -1162, -1163: R, 1979, v 21, p 349-350; Rothenberg, 1972; Rothenberg, Tylecote, and Boydell, 1978). Comments based on information supplied by P T Craddock, Research Lab, British Mus.

\section{BM-1368. Timna}

$\mathbf{3 0 3 0} \pm \mathbf{5 0}$

Charcoal from Site F2, Sq 3, Layer 3. Comment (PTC): Site F2 is $\delta^{1 s} C=-23.5 \%$ small smelting installation thought to have belonged to Chalcolithic period by analogy with adjacent sites, but date shows that it was contemporaneous with main, larger scale, late Bronze age smelting activities.

\section{BM-1598. Timna}

$$
2790 \pm 50
$$

Charcoal, ref Sample 684, from Timna-30, Layer 3. Comment (PTC) cf date for charcoal inclusions in slag from Timna-30 (Sample 632), $2480 \pm 35$ (BM-1162).

\section{Jericho series}

\section{H. Jordan}

Charcoal samples excavated from stratified levels in tell of Jericho $\left(31^{\circ} 50^{\prime} \mathrm{N}, 35^{\circ} 30^{\prime} \mathrm{E}\right)$. Coll ca 1955 and subm 1976 by Kathleen Kenyon as supplement to previous series (Burleigh, 1981).

BM-1320. Jericho $8540 \pm 65$ Charcoal, ref SA1009, JPM 6.11, from Site MI, phase XI.1v, PPNB.

BM-1321. Jericho

$\mathbf{9 2 3 0} \pm \mathbf{8 0}$

Charcoal, ref CS1002, JPF 300.1a, from Site FI, phase VIIIA.xvib, PPNA; cf BM-1326, below. 
BM-1322. Jericho

$9380 \pm 85$

Charcoal, ref CS1021, JPF 301.12, from Site FI, phase IVA.iiib, PPNA; cf BM-1327, below.

\section{BM-1323. Jericho}

$9380 \pm 85$ PPNA.

Charcoal, ref CS1017, JPF 303.16, from Site DI, phase VIA.x-xi,

\section{BM-1324. Jericho}

$9430 \pm 85$

Charcoal, ref SA954, JPE 13.14, from Sites EI, II, V, phase VI.xxvii, PPNA.

$\delta^{13} C=-24.9 \%$

\section{BM-1325. Jericho}

$40,500 \pm 2700$

$\delta^{13} \mathrm{C}=-28.0 \%$

Sample, ref SA754, JPM 7/6 (8), from Site MI, phase XIII.lxxiva; invalidated by misassoc.

BM-1326. Jericho

$$
9230 \pm 220
$$

$\delta^{13} C=-24.6 \% 0$

Charcoal, ref CS1001, JPF 300.1a, from Site FI, phase VIIIA.xvib, PPNA; $c f$ BM-1321, above.

\section{BM-1327. Jericho}

$9560 \pm 65$

Charcoal, ref CS1020, JPF 301.12, from Site FI, phase IVA.iiib, PPNA; $c f$ BM-1322, above.

\section{BM-1328. Jericho}

$4570 \pm 50$

Charcoal from Tomb A94 (Proto-Urban period); check on GL$24,5210 \pm 110$ (Zeuner, 1955, p 49) (different sample).

\section{BM-1329. Jericho}

$4500 \pm 60$

Charcoal from Tomb A94, same sample as GL-24; cf BM-1328, above.

\section{BM-1407. Jericho}

$$
11,090 \pm 90
$$

Charcoal, ref CS1029, JPE 515.41, from Sites EI, II, V, phase I.ii Mesolithic (Natufian).

General Comment (RB): for check-list of all BM-, GL-, Gro-, GrN-, and P- dates for Jericho (55 dates), see Burleigh, 1981; full assessment of these dates and supplementary series (19 dates; BM-XV, forthcoming) will appear in Jericho excavation mon, $\mathrm{v} 4$ (Burleigh, $\mathrm{ms}$ in preparation).

\section{Oman}

\section{BM-1352. Jabal al Hammah}

$$
\begin{array}{r}
1899 \pm 56 \\
\delta^{13} C=-24.9 \% \text { o }
\end{array}
$$

Cliarcoal, ref JH Pit 4, Layer 3, Sample 13 (prob Acacia sp) from base of firepit assoc with trilith site immediately $\mathrm{W}$ of track from Tawi 
Silaim to Mudaybi at N edge of Jabal al Hammah (Site 61; Doe, 1977), $2 \mathrm{~km} \mathrm{~W}$ of Ramlat al Wahiba, central Oman $\left(22^{\circ} 30^{\prime} \mathrm{N}, 58^{\circ} 40^{\prime} \mathrm{E}\right)$. Coll 1976 by $S$ Roskams and subm by Beatrice de Cardi. Comment (BdeC): known distribution of triliths extends from central Oman to Wadi Hadhramaut in S Arabia (Dostal, 1968) and this is 1st such site excavated in Oman; date suggests practice of erecting triliths is pre-Islamic in region and was probably introduced by frankincense traders or early immigrants from S Arabia (de Cardi, Doe, and Roskams, 1977, p 28).

\section{J. Peru}

\section{Early Peruvian domestic dogs series}

Samples of keratin (hair and skin) from mummified remains of domestic dogs from three archaeol sites in Peru: Ancon $\left(11^{\circ} 45^{\prime} \mathrm{S}, 77^{\circ}\right.$ $\left.10^{\prime} \mathrm{W}\right)$, Chancay $\left(11^{\circ} 35^{\prime} \mathrm{S}, 77^{\circ} 15^{\prime} \mathrm{W}\right)$ and Mala $\left(12^{\circ} 40^{\prime} \mathrm{S}, 76^{\circ} 35^{\prime} \mathrm{W}\right)$, from Forbes Colln (ca 1913), British Mus (Nat Hist) (Ancon samples) and colln of Lab of Palaeoethnozool, Univ San Marcos, Lima, Peru (Chancay and Mala samples). Subm by D R Brothwell, Inst Archaeol, Univ London.

BM-1236. Ancon

Keratin sample, ref 243.

BM-1237. Ancon

Keratin sample, ref 250.

BM-1238. Ancon

Keratin sample, ref 251.

BM-1239. Ancon

Keratin sample, ref 635 .

BM-1240. Ancon

Keratin sample, ref 729 .

BM-1359. Ancon

Keratin sample, ref DBa.

BM-1360. Ancon

Keratin sample, ref DBb.

BM-1361. Mala

Keratin sample, ref A157.

BM-1362. Chancay

Keratin sample, ref Al62 (skull).
$757 \pm 48$

$\delta^{1.3} \mathrm{C}=-14.1 \%$

$834 \pm 88$

$\delta^{13} C=-13.5 \%$

710 上 41

$\delta^{13} \mathrm{C}=-14.3 \%$

$1278 \pm 70$

$\delta^{13} \mathrm{C}=-15.1 \%$

$\mathbf{2 8 0 1} \pm \mathbf{8 7}$

$\delta^{1.3} C=-16.5 \%$

$949 \pm 50$

$\delta^{13} C=-13.1 \%$

$687 \pm 67$

$\delta^{13} \mathrm{C}=-12.8 \% \mathrm{c}$

$$
1365 \pm 77
$$

$\delta^{13} C=-17.3 \%$

$1077 \pm 122$

$\delta^{13} C=-12.1 \%$ 


\section{BM-1363. Chancay}

Keratin sample, ref A162 (post-cranial).

\section{BM-1364. Mala}

Keratin sample, ref A166.
$1420 \pm 221$

$\delta^{13} C=-12.1 \%$ o

$839 \pm 181$

$\delta^{13} C=-13.6 \%$ o

General Comment (RB): samples dated as part of program for comparative study of remains of early Amerindian dogs (Brothwell, Malaga, and Burleigh, 1979; Burleigh and Brothwell, 1978).

\section{K. Poland}

\section{BM-1235. Polany II}

$34.90 \pm 80$

Charcoal from Cutting I/72, Sq 10/III, depth 190 to $200 \mathrm{~cm}$ below surface in deposit of limestone rubble with karstic clay, base of Shaft no. 1, Polany II flint mine (Chmielewska, 1973), Polany, Szydlowiec dist, Poland $\left(51^{\circ} 15^{\prime} \mathrm{N}, 21^{\circ} 5^{\prime} \mathrm{E}\right)$. Coll 1972 and subm 1976 by Jacek Lech, Inst Hist Material Culture, Polish Acad Sci, Warsaw. Comment (JL): result dates flint mining activity to early Bronze age of Vistula catchment basin (late Mierzanowice/early Trzciniec cultures) and is youngest date for flint mining in region, but agrees with age expected for site (Lech, 1975); $c f$ date for late Danubian flint mine at Saspow, Olkusz dist, 5046 \pm 102 (BM-1128: R, 1979, v 21, p 350).

\section{Padina series}

\section{Yugoslavia}

Bone samples from Padina, Iron Gate gorge, Djerdap region $\left(44^{\circ} 40^{\prime}\right.$ $\mathrm{N}, 22^{\circ} 30^{\prime} \mathrm{E}$ ). Excavation on narrow strip of land along bank of Danube in advance of dam construction revealed human occupation site from which skeletal remains of 51 individuals were recovered. Coll 1968 and subm 1975 by S Živanović, Dept Anatomy, St Bartholomew's Hospital Medical Coll, London, to provide dates in support of anthropol study of Padina population (Živanović, 1975; 1976).

\section{BM-1143. Padina}

$7738 \pm 51$

Collagen from femur of Skeleton no. 2 (mature male), Sector I.

\section{BM-1144. Padina}

$8797 \pm 83$

Collagen from femur of Skeleton no. 7 (senile female), Sector III.

BM-1146. Padina

$9331 \pm 58$

Collagen from femur of Skeleton no. 12 (mature male), Sector III.

\section{BM-1147. Padina}

$9198 \pm 103$

Collagen from femur of Skeleton no. 14 (adult male), Sector III. 
BM-1403. Padina

$\delta^{13} C=-20.9 \%$

Collagen from fragmentary bones of bear (Ursus arctos), Sector III.

\section{BM-1404. Padina}

$9292 \pm 148$ III.

Collagen from post-cranial bones of Skeleton no. 39 (infant), Sector

General Comment (RB): dates confirm early Holocene (Mesolithic) age of Padina population (Burleigh and Živanović, 1980).

REFERENCES

Adams, B, 1974, Ancient Hierakonpolis Supplement: Warminster, Aris \& Phillips.

Bietak, M, 1979, Avaris and Piramesse: archaeological exploration in the eastern Nile delta (Mortimer Wheeler archaeol lecture, 1979): British Acad Proc, v 65, p 225-289, pls I-XXXVIIIb.

Bonsall, J C, 1981, The coastal factor in the Mesolithic settlement of north-west England: Veröffentlichungen des Museums für Urund Frühgeschichte Potsdam (Inter natl symposium on Mesolithic in Europe, 2nd, Potsdam, 3-8 April, 1978, Proc), v $14 / 15$, p $451-469$.

Brothwell, D, Malaga, A, and Burleigh, R, 1979, Studies on Amerindian dogs, 2: variation in early Peruvian dogs: Jour Archaeol Sci, v 6, p 139-161.

Burleigh, R, 1980, The date of Zibliyat: controversy settled by radiocarbon: Sumer, v 8 , no. 1-2, p 169-173.

1981, Radiocarbon dates, in Kenyon, K M (Holland, T A, ed), Excavations at Jericho, v 3, text, app C, p 501-504.

Burleigh, $\mathrm{R}$ and Brothwell, D, 1978, Studies on Amerindian dogs, $\mathrm{I}$ : carbon isotopes in relation to maize in the diet of domestic dogs from early Peru and Ecuador: Jour Archaeol Sci, v 5, p 355-362.

Burleigh, R and Clutton-Brock, J, 1977, A radiocarbon date for Bos primigenius from Charterhouse Warren Farm, Mendip: Univ Bristol Spelaeol Soc Proc, v 14, pt 3, p 255-257.

Burleigh, R and Živanović, S, 1980, Radiocarbon dating of a Cro-Magnon population from Padina, Yugoslavia, with some general recommendations for dating human skeletons: Zeitschr Morph Anthropol, v 70, p 269-274.

Bury, H, 1950, Blashenwell tufa: Bournemouth Nat Sci Soc Proc, v 39, p 48-51.

Case, H, 1959, Notes on the monuments and finds, in Catling, H W, 1959, A Beakerculture barrow at North Stoke, Oxon: Oxoniensia, v 24, p 8-12.

Case, $\mathrm{H}$ and Payne, J C, 1962, Tomb 100: the decorated tomb at Hierakonpolis: Jour Egyptian Archaeol, v 48, p 5-18, pl I.

Catling, H W, 1959, A Beaker-culture barrow at North Stoke, Oxon: Oxoniensia, v 24, p 1-12, pl I.

Chmielewska, M, 1973, Badania stanowiska Polany II w pow. Szydłowiec, w $1971 \mathrm{r}$ (the investigations of the site Polany II, district of Szydłowiec in 1971): Sprawozdania Archeol, v 25, p 29-37.

Clark, J G D, 1954, Excavations at Star Carr an early Mesolithic site at Seamer near Scarborough, Yorkshire: Cambridge, Cambridge Univ Press.

Clark, R M, 1975, A calibration curve for radiocarbon dates: Antiquity, v 49, p 251-266.

Clutton-Brock, J and Burleigh, R, 1979, Notes on the osteology of the Arab horse with reference to a skeleton collected in Egypt by Sir Flinders Petrie: Bull British Mus nat His (Zool ser), v 35, pt 2, p 191-200.

Coombs, D, 1976, Callis Wold round barrow, Humberside: Antiquity, v 50, p 130-131, pl XVI.

Cardi, B de, Doe, D B, and Roskams, S P, 1977, Excavation and survey in the Sharqiyah, Oman, 1976: Jour Oman Studies, v 3, p 17-33, pls VIIa-VIIIb.

Doe, D B, 1977, Gazetteer of sites in Oman, 1976: Jour Oman Studies, v 3, p 35-57, pls IX-XXb.

Dostal, W, 1968, Zur Megalithfrage in Südarabien, in Festschrift Werner Caskel: Leiden, Brill.

Evans, J D, 1971, Neolithic Knossos-the growth of a settlement: Prehist Soc Proc, v 37, pt 2, p 95-117, pls II-VIII. 
Everton, R F, 1975, A Bos primigenius from Charterhouse Warren Farm, Blagdon. Mendip: Univ Bristol Spelacol Soc Proc, v 14, pt 1, p 75-82.

Forsyth, G H, 1968, The Monastery of St Catherine at Mount Sinai: the church and fortress of Justinian: Dumbarton Oaks Papers no. 22, p 2-19, pls 1-50.

Forsyth, G H and Weitzmann, K, 1973, The Monastery of Saint Catherine at Mount Sinai: Ann Arbor, Univ Michigan Press.

Green, M, 1969, Godmanchester: Current Archaeol, no. 16, v 2, no. 5, p 133-138.

Hallam, J S, Edwards, B J N, Barnes, B, and Stuart, A J, 1973, The remains of a Late Glacial elk associated with barbed points from High Furlong, near Blackpool, Lancashire: Prehist Soc Proc, v 39, p 100-128, pls V-XII.

Hedges, J and Buckley, D, 1978, Excavations at a Neolithic causewayed enclosure. Orsett, Essex, 1975: Prehist Soc Proc, v 44, p 219-308, pls 21-26.

Kerney, M P, 1976, Two Postglacial molluscan faunas from southwest England: Jour Conchol, London, v 29, p 71-73.

1977, A proposed zonation scheme for Late-glacial and Postglacial deposits using land Mollusca: Jour Archaeol Sci, v 4, p 387-390.

Kerney, M P, Preece, R C and Turner, C, 1980, Molluscan and plant biostratigraphy of some Late Devensian and Flandrian deposits in Kent: Royal Soc (London) Philos Trans B, v 291, 1-43.

Libby, W F, 1955, Radiocarbon dating (2nd edn): Chicago, Univ Chicago Press.

Lech, J, 1975, O Konieczności ochrony prahistorycznych kopalń krzemienia uwagi i postulaty (the necessity of protecting prchistoric flint mines - remarks and postulates): Wiadomości Archeol, v 40, p 139-148.

Martin, G T, 1976, Excavations at the Memphite tomb of Horemheb, 1975: preliminary report: Jour Egyptian Archaeol, v 62, p 5-13, pls I-IV.

1979, Excavations at the Memphite tomb of Horemheb, 1978: preliminary report: Jour Egyptian Archaeol, v 65, p 13-16, pls II-III.

Molleson, T and Burleigh, R, 1978, A new date for Goat's Hole Cave: Antiquity, v 52, p 143-145.

Mortimer, J R, 1905, Forty years researches in British and Saxon burial mounds of East Yorkshire: London, A Brown \& Sons.

Payne, J C, 1973, Tomb 100: the decorated tomb at Hierakonpolis confirmed: Jour Egyptian Archaeol, v 59, p 31-35, pls XXIII-XXV.

Postga e, I N, 1977, Excavations at Abu Salabikh, 1976: Iraq, v 39, p 269-299, pls XXXI-XXXIV.

1978, Excavations at Abu Salabikh, 1977: Iraq, v 40, p 77-88, pl XIII.

1980a, Excavations at Abu Salabikh, 1978-79: Iraq, v 42, p 87-104, pls X-XI.

1980b, Palm-trees, reeds and rushes in Iraq ancient and modern, in L'archéologie de l'Iraq: perspectives et limites de l'interprétation anthropologique des documents (CNRS Internatl Colloq no. 580, 13-15 June, 1978): Paris, CNRS, p 99-111.

Postgate, J N and Moorey, P R S, 1976, Excavations at Abu Salabikh, 1975: Iraq, v 38, p 133-169, pls XX-XXVII.

Preece, R C, ms, 1978, The biostratigraphy of Flandrian tufas in southern Britain: unpub PhD thesis, Univ London.

1980, The biostratigraphy and dating of the tufa deposit at the Mesolithic site at Blashenwell, Dorset, England: Jour Archaeol Sci, v 7, p 345-362.

Quibell, J E and Green, F W, 1902, Hierakonpolis pt II: London, Bernard Quaritch.

Reid, C, 1896, An early Neolithic kitchen midden and tufaceous deposit at Blashenwell. near Corfe, Dorset: Dorset Nat Hist and Antiquarian Field Club Proc, v 17, p 67-75.

Rothenberg, B, 1972, Timna-valley of the Biblical copper mines: London, Thames and Hudson.

Rothenberg, B, Tylecote, R F and Boydell, P J, 1978, Chalcolithic copper smelting (Archaeo-Metallurgy, IAMS Mono no. 1): London, Inst Archaeo-Metallurgical
Studies. Saxon, E C, 1979, Natural prehistory: the archaeology of Fuego-Patagonian ecology:
Quaternaria, v 21, p 329-356.

Wendorf, F and Schild, R, 1976, Prehistory of the Nile Valley: London, Academic Press.

Zeuner, F E, 1955, Radiocarbon dates, in Univ London Inst Archaeol: Ann Rept 11. p 43-50.

Zivanović, S, 1975, A note on the anthropological characteristics of the Padina population: Zeitschr Morph Anthropol, v 66, p 161-175.

p 518. 1976, Cromagnon in the Iron Gate Gorge of the Danube: Nature, v 260. 